\title{
PHARMACY EDUCATION AND PROFESSION IN LIBYA: FUTURE PERSPECTIVE
}

Abdulla Salem Elhwuegi ${ }^{1}$, Mustafa Mohammed Elfakhri ${ }^{2}$, Abubaker Ahmed Basher ${ }^{2}$

1) Faculty of Pharmacy, Tripoli University, Tripoli Libya, 2) Faculty of Pharmacy, Benghazi

University, Benghazi Libya.

Received: 31 December 2013, Accepted in revised form: 11 March 2013, Published: 3 April 2013

Corresponding author: Abdulla Salem Elhwuegi, e - mail: hwuegi@hotmail.com

\section{INTRODUCTION:}

$\mathbf{F}$ Torty two years of the brutal Ghadafi regime has left education in Libya in a ruin. Pharmacyeducation and practice in Libya, among other professions, is facing multiple challenges that require the effort of academics and professionals to Accomplish the following tasks:-

- The development of national academic reference standards for pharmacy Education and the implementation of efficient modern academic programs to ensure high quality pharmacy graduate that fulfill community needs.

- The continuous education of pharmacy graduates to ensure good pharmacy practice to keep up with the fast change and rapid evolution in the profession.

- The continuouse valuation of the pharmacy profession to meet local demands and ensure development.

- Preparing pharmacy profession leaders to take an active role in the development of national drug policies and health care.

\section{THE PRESENT SITUATION OF PHARMACY EDUCATION AND PROFESSION:}

Pharmacy education and profession in Libya is suffering from many inadequacies which include the followings:

- The absence of a national vision and policy that govern pharmacy education and profession in general. This is a prerequisite to satisfy the community needs for an integrated health system managed according to international standards.

- The old traditional pharmacy curriculum
Which was established more than 35 years ago. This curriculum never been reviewed Upgraded or developed. These programs suffered from unplanned Expansion with accumulation of Knowledge that makes the curriculum unappealing, difficult to Comprehend and does not correspond with the market need. Moreover, these programs aren't implementing the modern quality assurance system and lack the ability to teach the student the relevant clinical skills needed after graduation.

- The random opening of new pharmacy colleges in different parts of Libya without taking into account the specific goals and outcomes of the programs offered. These programs were initiated without taking into account the basic minimum package of infrastructure which is required for effective teaching and learning. These three major Inadequacies, among many others, have resulted in the graduation of many incompetent pharmacists who had very little impact on the health services in general.

\section{WHAT WE SHOULD DO?}

Actions to improve education and the pharmacy profession in Libya should be planned at three different levels, the government, the academics and at the pharmacy syndicate levels.

\section{A. At The Government Level.}

A national policy for the pharmacy profession including pharmacy education is urgently needed. At the education level we should establish national criteria for starting a new program or approving an existing one. This

Copyright $\odot$ 2013. LJPCP. This is an open access article distributed under the Creative Commons Attribution 3.0 License, which permits unrestricted use, distribution, and reproduction in any medium, provided the original work is properly cited. 
would prevent the development of new pharmacy program that doesn't have the minimum re quirements. Furthermore, there should be national academic reference Standards for the pharmacy programs; starting from acceptancecriteria, methods of evaluation of performances, to the minimum graduation requirements. The government should specify what arethe general outcomes

expected in the pharmacy graduate. We should, as well, have academic standers for the faculty member appointment, their Evaluation and assessment.

\section{B. At The Level of the Faculties of Pharmacy.}

The faculties of pharmacy need strong leadership with clear visions and strategies. All faculty members should have special training on quality assurance (Q.A.) system in order to close the gap between vision and performance. Afterthat all pharmacy programs should be upgraded to fulfill the Q.A. Standards including intended goals and outcomes, good curriculum design, content and organization. We have as well to change and improve our teaching, learning and assessment methods. In another word, the whole program and its component should be subjected to assessment with the implementation of total quality management procedures.

\section{At The Pharmacist Syndicate Levels.}

At present time license to practice the profession of pharmacy to pharmacy graduates are granted by the Libyan Pharmacists Syndicate without exposure to any qualification exam. Therefore, we should establishthe Libyan Pharmacy Examination Board to carry out the national pharmacy qualification examinations to issue and maintain pharmacy practice licensing. This board should have strong qualified leadership with a vision that can provide the required changes in the profession of pharmacy. At the present time the Libyan Pharmacists Syndicate does not have any role in the development or implementation of national health Policies, this must change. Furthermore, professional licensing should be conditioned with the involvement in the continuous education and development programs. The Libyan Pharmacists Syndicate through advertising and Active presence in the society should enhance the image and credibility of pharmacists in the society.

\section{CONCLUSION:}

Abdulla Salem Elhwuegi et al

Improving the Libyan pharmacy programs to meet the future needs is possible by the application of a comprehensive system that involves the three levels; the government, the academia and the pharmacy syndicate. It can be achieved through adopting a well-designed national policy, which should be implemented by well-qualified and trained leaderships at the three levels mentioned above. With a comprehensive strategicplan, the advancement of the Libyan pharmacy programs and

Profession can take up to 15 years of continuous training and development.

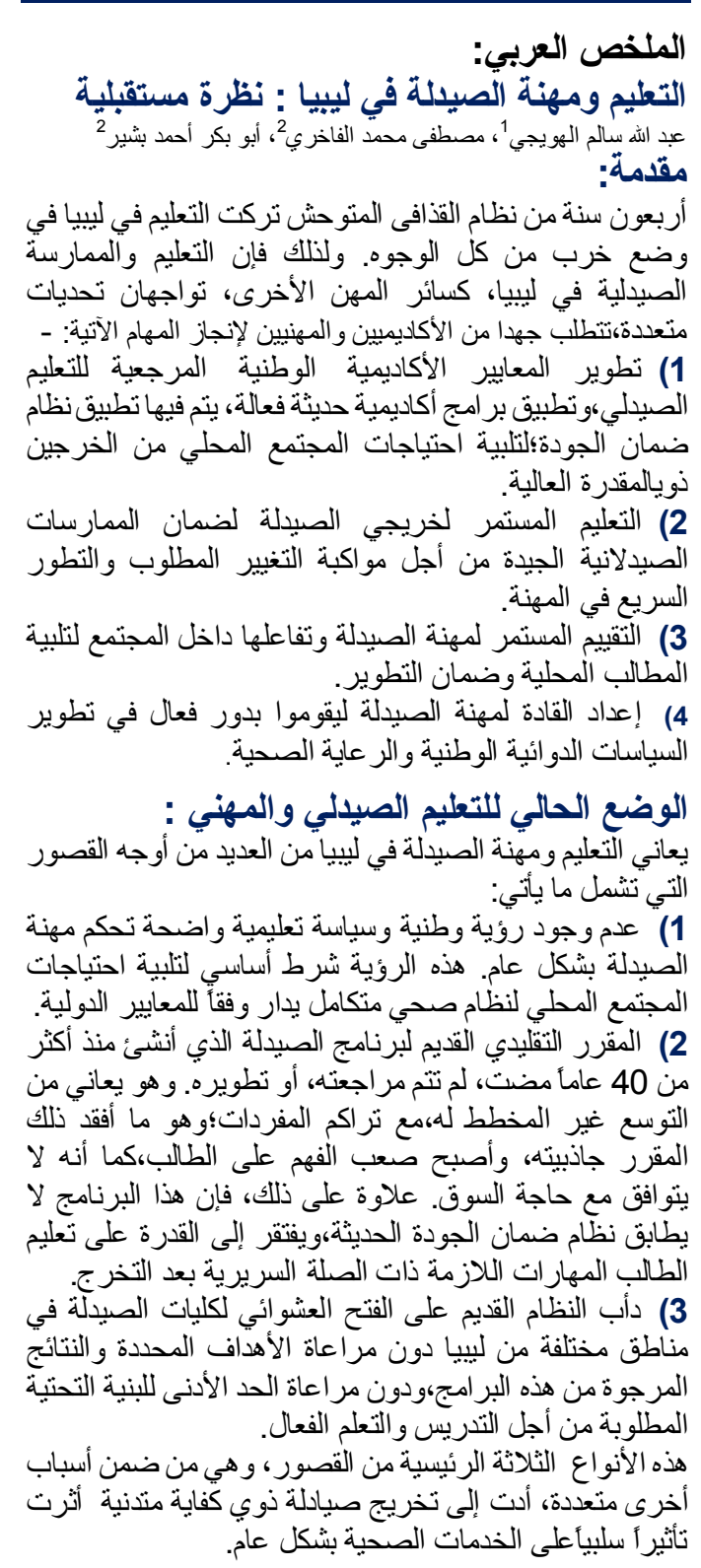




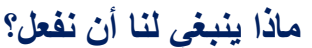

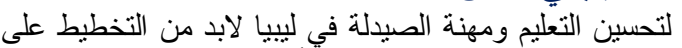

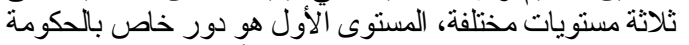

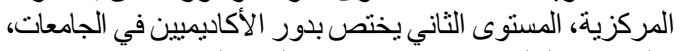
والمستوى الثالث يختص بنور نقابة الصيادلة.

أولاً: المستوى الأول دور الحكومة المركزية:

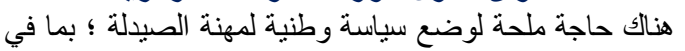

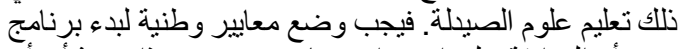

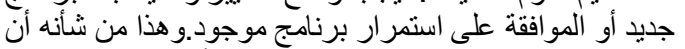

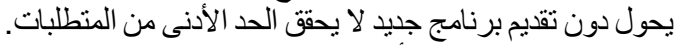

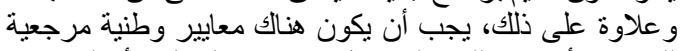

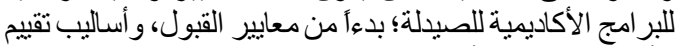

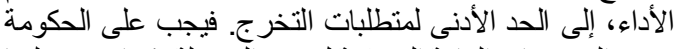

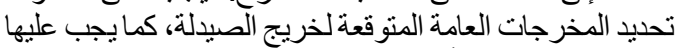
كنللك وضع معايير الأكاديمية الخاصة بنتيعيين عضو هيئة التنريس وتقييم أدائه في مثل هذه البرامج.

ثانياً: المستوى الثاني دور كليات الصيدلة:

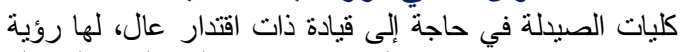

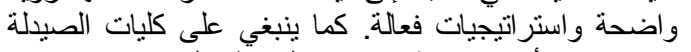

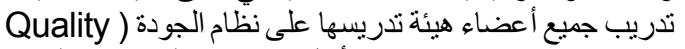
(assurance system والأداء. وينبغي بعد ذلك أن ينت تطوير جميع معايير الأكاديمية

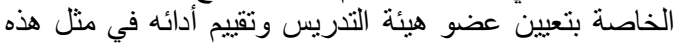

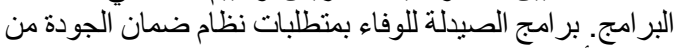

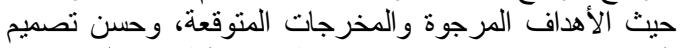

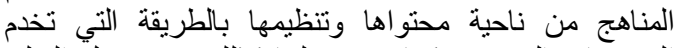

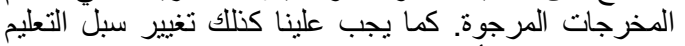

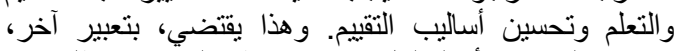
إخضاع البرنامج بأكله لكل إجراءات نظام الجودة ومتطلباته.

ثالثاً: على مستوي نقابة الصيادلة في ليبيا:

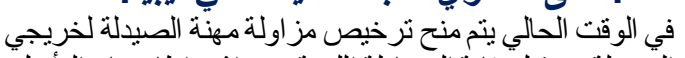

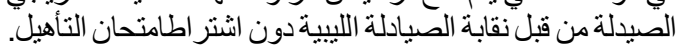

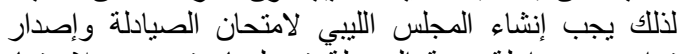

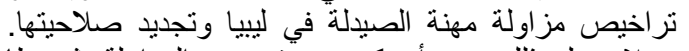

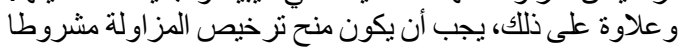

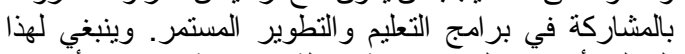

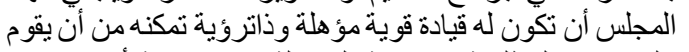

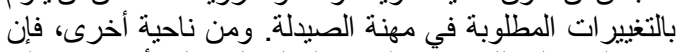

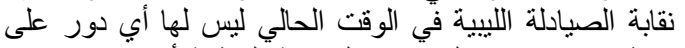

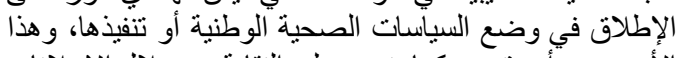

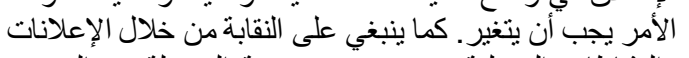

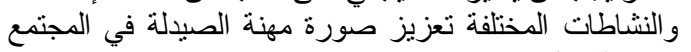
ومصداقيتها .

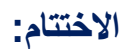

بالإمكان تحسين برامج الصيلة لتلبية الاحتياجات المستقلية

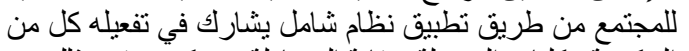

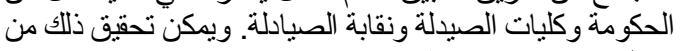

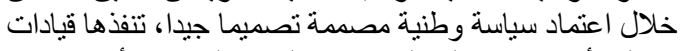

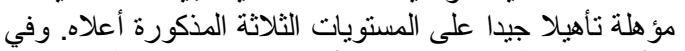

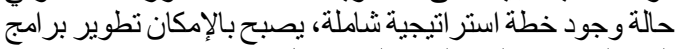
الصيدلة ومهنة الصيليلة في ليبيا خلال فترة قد تستغرق 15 عاميا من التندريب و التطوير المستمر. 